\title{
Analysis of the different techniques for calculation of bearing capacity of flexural reinforced concrete deep beams
}

\author{
Beata Levon ${ }^{1}$, Remigijus Šalna ${ }^{2}$, Linas Juknevičius ${ }^{3}$ \\ Department of Reinforced Concrete Structures and Geotechnics, \\ Vilnius Gediminas Technical University, Vilnius, Lithuania \\ E-mail: 'beata.levon@gmail.com (corresponding author)
}

\begin{abstract}
The paper deals with the singularities of the design of deep beams without shear reinforcement according to different design codes, namely, STR 2.05.05:2005, EC2, EC2-SMM and ACI-318. The comparative analysis of calculation models, experimental verification, accuracy of models and the ranking of models according to the Modified Demerit Points Classification (MDP) method are presented. The results shown that despite the systematic error of the STR 2.05.05:2005 method is closest to 1 if compared to the other methods, it is classified as dangerous one according to the MDP ranking.
\end{abstract}

Keywords: reinforced concrete, deep beam, carrying capacity, analysis, design methods, accuracy.

\section{Introduction}

Deep reinforced concrete beams could be used for the construction of ground beams, foundation caps, column supports, bridge transverse beams and other important structural members. However, the design methodologies (codes) in the different countries vary considerably. It shows that the factors like concrete strength, longitudinal reinforcement ratio, shear span and effective height ratio are estimated in a different way. Besides, the main assumptions, calculation schemes and calculation models are also different. These factors lead to different calculation results, including load bearing capacity, material economy and different overall design reliability. In addition, there are two design codes in Lithuania with three essentially different calculation models (STR 2.05.05:2005, EC2 and EC2-SMM), which result in three different load bearing capacities when designing the same structure in the same country. Thus, it is necessary to analyze the above-mentioned design models by comparing them with experimental data, determining their accuracy and the main factors influencing carying capacity of the deep beams. In a same context, it is also interesting and valuable to include the American design codes (ACI-318) in this analysis.

\section{Calculation models of deep beams according to different design codes}

According to Lithuanian design codes, deep beams could be calculated in three different ways: (1) according to STR 2.05.05:2005, where calculation model is based on the failure of compression zone in projection of shear section; (2) according to EC2 empirical model, which determines shear stress acting in cross-sectional area; and (3) according to EC2-SMM (strut-tie) model, which estimates the failure of the strut. All these methods are fundamentally different and subsequently leads to different results of caryying capacity. There are some similarities of the methods: all of them evaluate the strength of the concrete, the amount of longitudinal reinforcement, the shear span to effective height ratio (a/d). However, all these factors are evaluated by different empirical expressions, for example, according to STR 2.05.05:2005 concrete shear stresses can be expressed as $0.3 f_{c}^{2 / 3}$, according to EC2 $-\left(100 \cdot \rho_{1} \cdot f_{c}\right)^{1 / 3}$, according to EC2-SMM $-0.36 f_{c}\left[1-\frac{f_{c}}{250}\right]$. American design codes estimate concrete strength as $0.156 \sqrt{f_{c}}$. It must be pointed out, that one of the most important factors is the ratio of shear span to effective height (or acting moment to shear force ratio M/V). Unfortunately, in the design codes STR2.05.05: 2005 this factor is not evaluated at all. Meanwhile, EC2, EC2-SMM and ACI-318 evaluate this factor, but in a different way. The a/d ratio in EC2 model is assesed in calculation directly. Instead, the the beam height effect expressed through the coefficient k. EC2-SMM model for

(C) 2019 Authors. Published by VGTU Press. This is an open-access article distributed under the terms of the Creative Commons Attribution (http://creativecommons.org/licenses/by/4.0/) License, which permits unrestricted use, distribution, and reproduction in any medium, provided the original author and source are credited. 
such purpose uses the strut angle $\theta$, and the ACI-318 model uses directly the M/V ratio. The key formulas of all mentioned design models are given in Appendix 1, Table 1. The typical calculation scheme is presented in Figure 1.

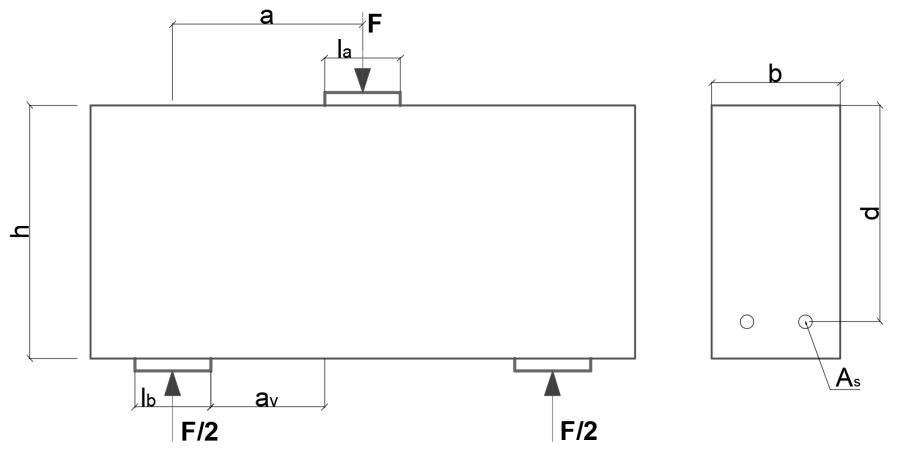

Figure 1. Typical calculation scheme of the deep beam

\section{Verification by experimental data}

Calculation models given in different design codes were verified by the numerical calculations and comparison to the experimental data of deep beam tests carried out by various authors. The experimental data of 212 beams without shear reinforcement were collected in available literature sources (Appendix 1, Table 2). The shear span to effective height ratio of the analyzed beams vary from 0.67 to 2 and the concrete compressive strength vary from $12 \mathrm{MPa}$ to $87 \mathrm{MPa}$. The amount of longitudinal reinforcement in the tested deep beams vary between 0.57 to $4.76 \%$, although the maximum reinforcement ratio values allowed in the design codes (when exceeding) were used in numerical calculations. Other parameters of experimental beams were also different, but they considered as less significant. Some deep beam specimens do not match the sizes used in construction, such as a beam width only $51 \mathrm{~mm}$, concrete strength greater than $80 \mathrm{MPa}$ or longitudinal reinforcement ratio that do not meet the general detailing requirements $\left(0.5 \%<\rho_{l}>2 \%\right)$. All of the test beams were tested by hydraulic testing machines. The load was applied through the steel plates and the load application velocity ranged from 0.02 to $0.05 \mathrm{kN} / \mathrm{s}$. The main results of the numerical calculations are shown graphically in the Figures 2 to 5.

Figures 2-5 presents the influence of different factors to the $V_{\text {test }} / V_{\text {calc }}$ value, namely, the width of deep beam $b$, shear span to effective height ratio a/d, concrete compressive strength $f_{c}$ and longitudinal reinforcement ratio $\rho_{\mathrm{l}}$. The linear regression analysis is performed based on experimental data presented in Table 1 . The figures show the regression equations of the calculation models and the coefficients of determination $R^{2}$.

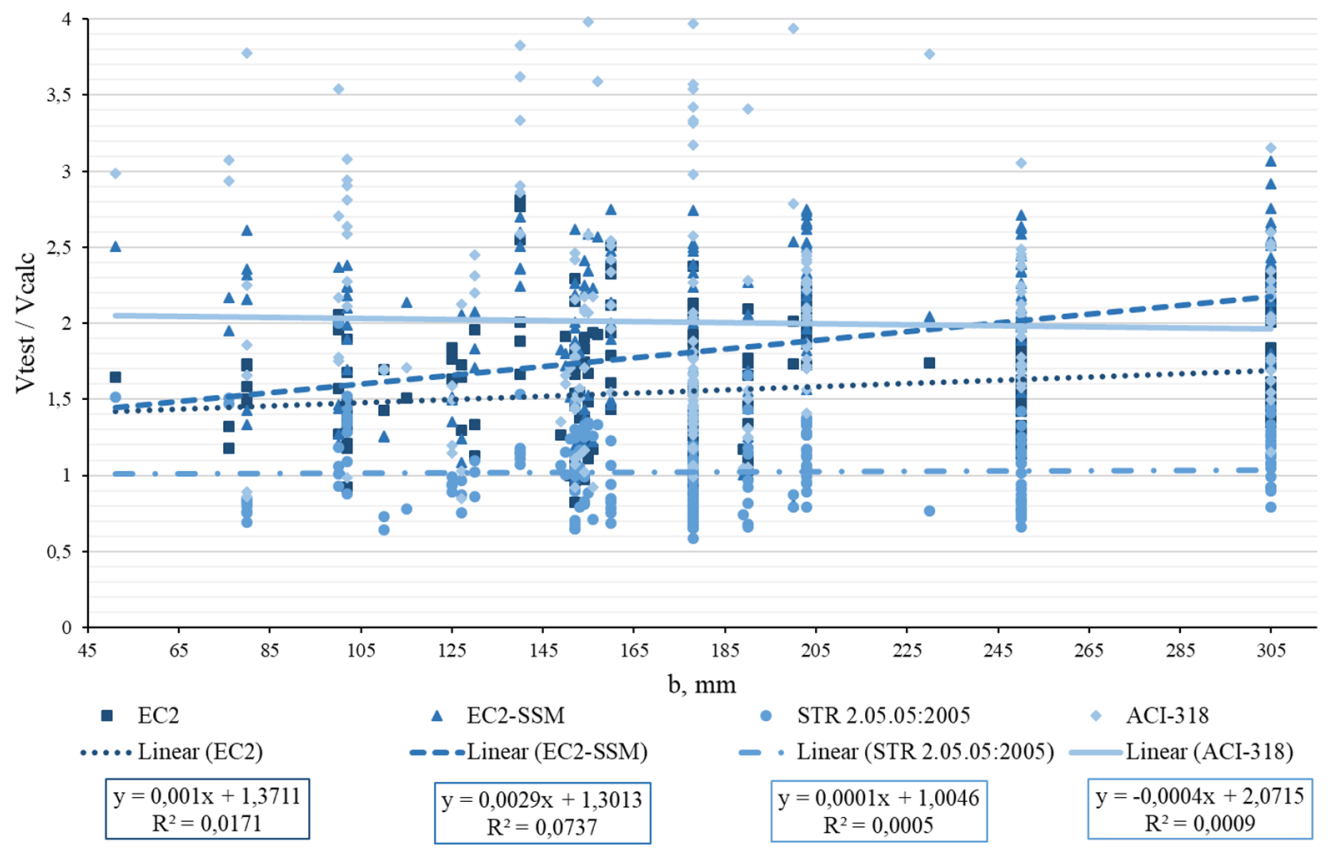

Figure 2. $V_{\text {test }} / V_{\text {calc }}$ ratio versus the width of deep beam $b$ 
Figure 2 shows the influence of the width of the beam $b$ by comparing the the experimental and theoretical results of the deep beams without shear reinforcement. The presented regression equations show, that in this case the maximum value of the free member is 2.07 for the model provided by ACI-318. It means that the experimental load bearing capacity of an average deep beam is 2 times higher than the theoretical loading bearing capacity determined by this model. The minimum error is in the model STR 2.05.05:2005 and equals to 0.5\%. A positive direction of regression lines indicates that by increasing the beam width $\mathrm{b}$, the $V_{\text {test }} / V_{\text {calc }}$ ratios also increase. The given determination coefficients $R^{2}$ show that the relationship between all models is very weak. The conclusion can be done that the ratio of $V_{\text {test }} / V_{\text {calc }}$ is linearly independent from the width of the beam b.

Figure 3 shows the influence of the a/d ratio by comparing the the experimental and theoretical results of the deep beams without shear reinforcement. The regression equations presented in Figure 3 show that the maximum value of the free member is 3.42 for the model given in ACI-318, which means that the average deep beam experimental load capacity is 3.42 times higher than the theoretical load bearing capacity determined by this calculation model. The minimum error is again found in the STR 2.05.05:2005 model and equals to 25\%. The negative angle of regression lines indicates that by increasing the a/d ratio, the $V_{\text {test }} / V_{\text {calc }}$ ratios decrease. The obtained determination coefficients $R^{2}$ shows that the relationship between the ACI-318 code model is weak, and the other models are even weaker. Similary to previous example, the ratio $V_{\text {test }} / V_{\text {calc }}$ is not linearly dependent on the a/d ratio.

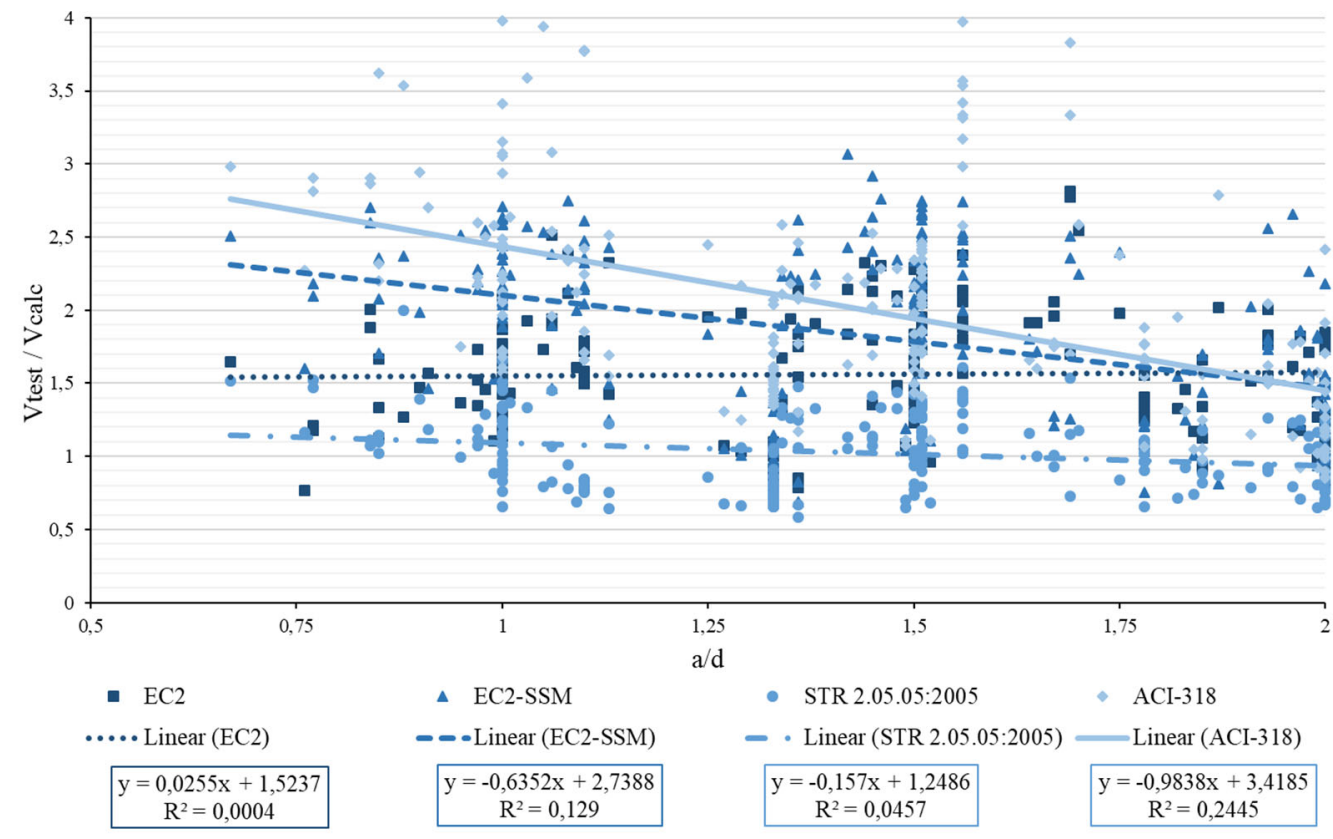

Figure 3. $V_{\text {test }} / V_{\text {calc }}$ ratio versus shear span to effective height ratio $a / d$

Figure 4 shows the influence of the compressive strength of the concrete $f_{c}$ by comparing the the experimental and theoretical results of the deep beams without shear reinforcement. The presented regression equations shows that the maximum value of the free member is 2.2 for the EC2-SSM calculation model, which means that the average deep beam experimental load bearing capacity is 2.2 times higher than the theoretical load bearing capacity obtained by this model. The minimum error is 13\% for the STR 2.05.05:2005 model. The determination coefficients $R^{2}$ shows that the relationship of all models is very weak. The ratio of $V_{\text {test }} / V_{\text {calc }}$ is not linearly dependent on the compressive strength of the concrete $f_{c}$.

Figure 5 shows the influence of the longitudinal reinforcement ratio $\rho_{1}$ by comparing the the experimental and theoretical results of the deep beams without shear reinforcement. It should me noted that the effect of longitudinal reinforcement ratio is not evaluated at all in the STR 2.05.05:2005 and EC2-SSM calculation models. The regression equations show that the maximum value of the free member is 1.99 for the model given in ACI-318 code, which means that the experimental load bearing capacity of an average deep beam is $99 \%$ higher than the theoretical one. The determination coefficients $R^{2}$ show that the relation between $V_{\text {test }} / V_{\text {calc }}$ and $\rho_{l}$ is very weak. Also, the ratio $V_{\text {test }} / V_{\text {calc }}$ is not linearly dependent on the longitudinal reinforcement ratio $\rho_{l}$. 


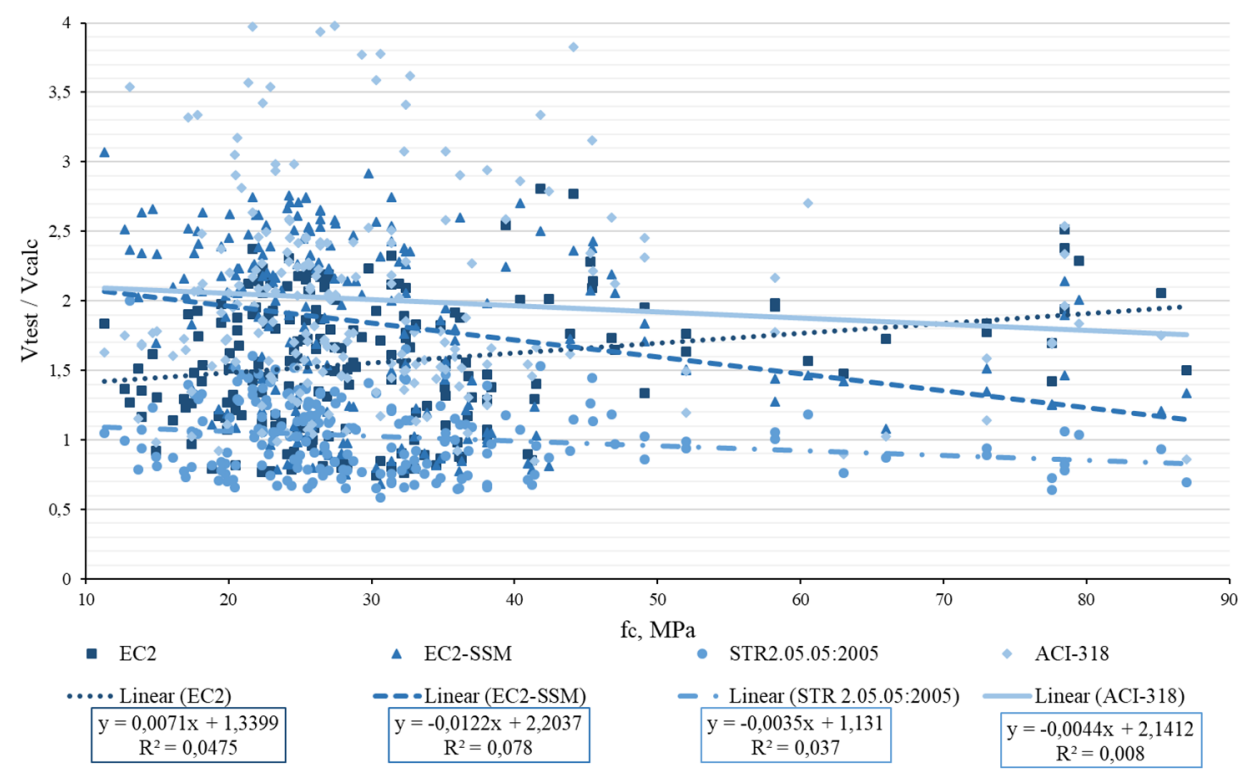

Figure 4. $V_{\text {test }} / V_{\text {calc }}$ ratio versus concrete compressive strength $f_{c}$

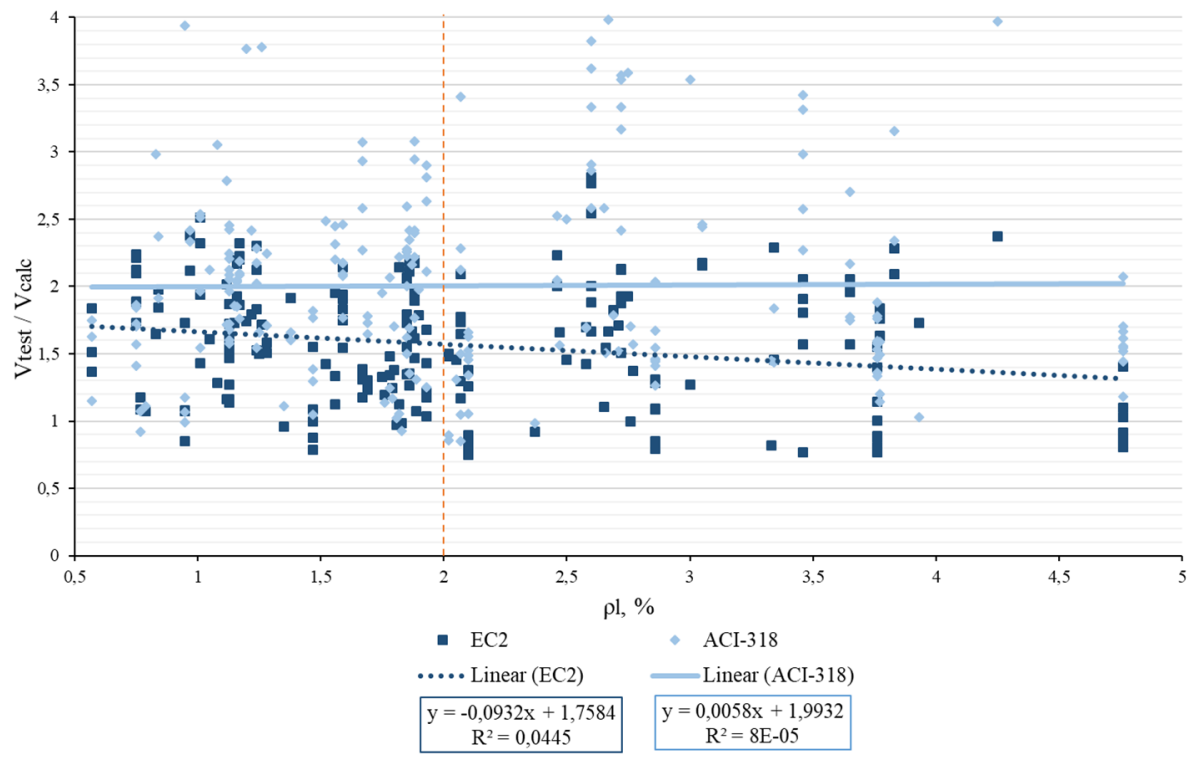

Figure 5. $V_{\text {test }} / V_{\text {calc }}$ ratio versus longitudinal reinforcement ratio $\rho l$

\section{The accuracy of calculation models}

The analysis of systematic and random errors of the models under consideration is carried out by comparing the experimental and numerical results of 212 specimens (tested deep beams). The main results of this analysis are presented in Appendix 1, Table 3.

The highest systematic error is resulted by using the ACI-318 design code model. The most accurate results are obtained by using the calculation model given in STR 2.05.05:2005 design code. The systematic error is equal to 1.02. The summarized $V_{\text {test }} / V_{\text {calc }}$ graphical interpretation with a $67 \%$ confidence interval is presented in Figure 6 .

The calculation models given in different design codes could be also evaluated by other criteria, such as Modified Demerit Points Classification (DPC). The methodology based on the following evaluation system: when the systematic error is greater than $2-2$ penalty points are awarded for the calculation model; when the systemic error ranges between 1.15 and 2 - penalty is 1 point; when systemic error varies between 0.85 and $1.15-0$ penalty points are given; when systemic error ranges between 0.50 and $0.85-5$ penalty points are given and finally, 10 penalty points are awarded when systemic error is less than 0.5 . The calculation models are then ranked according to the sum of the awarded penalty points. The results presented in Appendix 1, Table 4, show that according to this evaluation method all analyzed design codes could be ranked in the following order: the most accurate method is EC2, second best is ACI-318, the third is EC2-SSM and the least accuarate is STR 2.05.05:2005. 


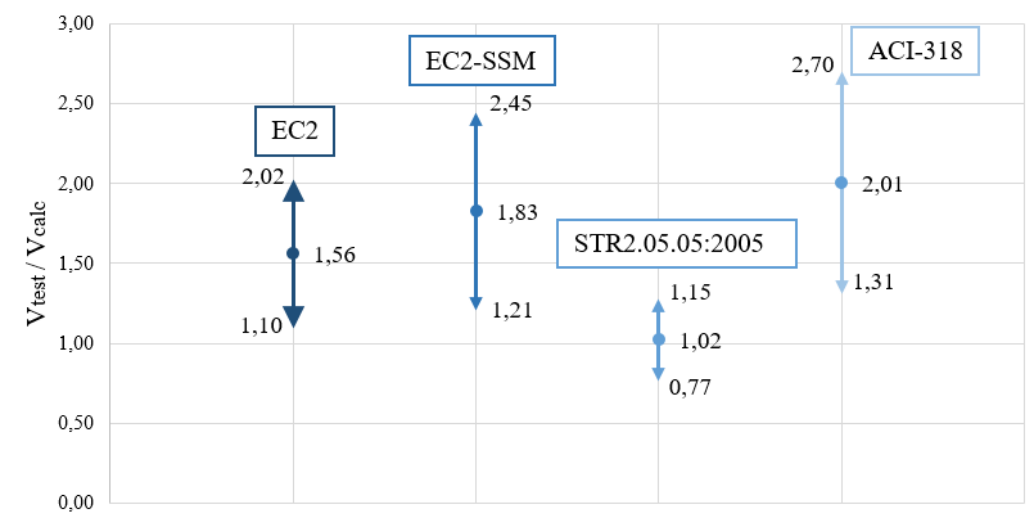

Figure 6. $V_{\text {test }} / V_{\text {calc }}$ ratio with a $67 \%$ confidence interval according to different design codes

\section{Conclusions}

The regression analysis of experimental and numerical results of deep beams with varying the width of the beam $b$, shear span to effective height ratio $a / d$, concrete compressive strength $f_{c}$ and longitudinal reinforcement ratio $\rho_{l}$. has shown that the $V_{\text {test }} / V_{\text {calc }}$ ratio is not linearly dependent on all these factors.

The comparison of experimental and numerical load bearing capacity values for deep beams has shown, that the systematic error of all design codes exceeds value of 1.0. The most accurate code based on systematic error is STR 2.05.05:2005. According to the systematic and random errors the codes could be ranked in the following order: STR 2.05.05:2005 (1.02; 0.26), EC2 (1.56; 0.46), EC2-SSM (1.83; 0.62) and ACI-318 (2.01; 0.70).

The calculation models were also ranked according to Qualification of Models of the Demerit Points Classification (DPC) method (Neto, Barros, \& Melo, 2013). Unfortunately, this evaluation method gives the opposite ranking results. The codes are ranked in the following order: EC2, ACI-318, EC2-SSM and STR 2.05.05:2005.

According to DPC method, the calculation model given in STR 2.05.05:2005 collects the equal number of penalty points in three categories: Dangerous, Appropriate safety and Conservative. It is the main reason which caused the highest number of penalty point among all evaluated models. It must be taken into account by structural engineers while designing the deep beams and by using probabilistic methods, which assess systematic and random errors of the models.

\section{References}

ACI Committee 318-05. (2005). Building code requirements for reinforced concrete. American Concrete institute, Detroit.

Adebar, P. (2000). One-way shear strength of large footings. Canadian Journal of Civil Engineering, 27(3), 553-562. https://doi.org/10.1139/100-008

Chang, T. S., \& Kesler, C. E. (1958). Static and fatigue strength in shear of beams with tensile reinforcement. ACI Journal Proceedings, 54(6), 1033-1057. https://doi.org/10.14359/11493

de Cossio, R. D., \& Siess, C. P. (1960). Behavior and strength in shear of beams and frames without web reinforcement. ACI Journal Proceedings, 56(2), 695-736. https://doi.org/10.14359/8118

de Paiva, H. R., \& Siess, C. P. (1965). Strength and behavior of deep beams in shear. ASCE Structural Journal, 91(ST5), 19-41. https://e-seimas.lrs.lt/portal/legalAct/lt/TAD/TAIS.249853?jfwid=rivwzvpvg

Ismail, K. S. (2016). Shear behaviour of reinforced concrete deep beams (Doctoral thesis, 391). University of Sheffield. $313 \mathrm{p}$. http://etheses.whiterose.ac.uk/12600/

Kani, G. N. J. (1967). How safe are our large reinforced concrete beams? ACI Structural Journal, 64(3), 128-141. https://doi.org/10.14359/7549

Leonhardt, F., \& Walther, R. (1964). The Stuttgart shear tests. C\&CA Translation, No. 111. Cement and Concrete Association, London. $134 \mathrm{p}$.

Lietuvos Respublikos aplinkos ministerija. (2005). Statybos techninis reglamentas: Betoniniu ir gelžbetoniniu konstrukcijų projektavimas (STR 2.05.05:2005). Vilnius. Retrieved from

Lietuvos standartizacijos departamentas. (2005). Eurokodas 2. Gelžbetoniniu konstrukciju projektavimas. 1-1 dalis. Bendrosios ir pastatu taisykles (LST EN 1992-1-1:2005). Vilnius.

Manuel, R. (1974). Failure of deep beams. ACI Special Publication, 42, 15.

Moody, K., Viest, I. M., Elstner, R., \& Hognestad, E. (1954). Shear strength of reinforced concrete beams Part 1 - Tests of simple beams. ACI Journal Proceedings, 26(4), 317-332.

Moody, K., Viest, I. M., Elstner, R., \& Hognestad, E. (1955). Shear strength of reinforced concrete beams Part 2 - Tests of restrained beams without web reinforcement. ACI Journal Proceedings, 26(5), 417-434. 
Morrow, J., \& Viest, I. M. (1957). Shear strength of reinforced concrete frame members without web reinforcement. ACI Journal Proceedings, 53(3), 833-869. https://doi.org/10.14359/11558

Neto, B. N. M., Barros, J. A. O., \& Melo, G. S. S. A. (2013) Model to simulate the contribution of fiber reinforcement for the punching resistance of RC slabs. Journal of Materials in Civil Engineering, 26(7). https://doi.org/10.1061/(ASCE)MT.19435533.0000913

Niwa, J., Maekawa, K., \& Okamura, H. (1981). Non-linear finite element analysis of deep beams. In IABSE Colloquium Delft on Advanced Mechanics of Reinforced Concrete (pp. 625-638).

Oh, J. K., \& Shin, S. W. (2001). Shear strength of reinforced high-strength concrete deep beams. ACI Structural Journal, 98(2), 164-173. https://doi.org/10.14359/10184

Pendyala, R. S., \& Mendis, P. (2000). Experimental study on shear strength of high-strength concrete beams. ACI Structural Journal, 97(4), 564-571. https://doi.org/10.14359/7421

Rodriguez, J. J., Bianchini, A. C., Viest, I. M., \& Kesler, C. E. (1959). shear strength of two-span continous reinforced concrete beams. ACI Structural Journal, 55(4), 1089-1130. https://doi.org/10.14359/11409

Rogowsky, D. M., MacGregor, J. G., \& Ong, S. Y. (1986). Tests of reinforced concrete deep beams. ACI Journal Proceedings, 83(4), 614-623. https://doi.org/10.14359/10558

Shin, S. W., Lee, K. S., Moon, J. I., \& Ghosh, S. (1999). Shear strength of reinforced high-strength concrete beams with shear spanto-depth ratios between 1.5 and 2.5. ACI Structural Journal, 96(4), 549-556. https://doi.org/10.14359/691

Smith, K., \& Vantsiotis, A. (1982). Shear strength of deep beams. ACI Journal Proceedings, 79(3), $201-213$. https://doi.org/10.14359/10899

Tan, K. H., Kong, F. K., Teng, S., \& Guan, L. (1995). High-strength concrete deep beams with effective span and shear span variations. ACI Structural Journal, 92(4), 395-405. https://doi.org/10.14359/991

Tan, K., \& Cheng, G. (2006). Size effect on shear strength of deep beams: Investigating with strut-and-tie model. Journal of Structural Engineering, 132(5), 673-685. https://doi.org/10.1061/(ASCE)0733-9445(2006)132:5(673)

Tan, K., Cheng, G., \& Cheong, H. (2005). Size effect in shear strength of large beams-behaviour and finite element modelling. Concrete Research, 57(8), 497-509. https://doi.org/10.1680/macr.2005.57.8.497

Walraven, J., \& Lehwalter, N. (1994) Size effects in short beams loaded in shear. ACI Structural Journal, 91(5), 585-593. https://doi.org/10.14359/4177

Watstein, D., \& Mathey, R. G. (1958). Strains in beams having diagonal cracks. ACI Journal Proceedings, 55(6), $717-728$. https://doi.org/10.14359/11384

Yang, K. H., Chung, H. S., Lee, E. T., \& Eun, H. C. (2003). Shear characteristics of high-strength concrete deep beams without shear reinforcements. Engineering Structures, 25(10), 1343-1352. https://doi.org/10.1016/S0141-0296(03)00110-X

Xie, Y., Ahmad, S. H., Yu, T., Hino, S., \& Chung, W. (1994). Shear ductility of reinforced concrete beams of normal and highstrength concrete. ACI Structural Journal, 91(2), 140-149. https://doi.org/10.14359/4592

Zhang, N., \& Tan, K. H. (2007). Size effect in RC deep beams: Experimental investigation and STM verification. Engineering Structures, 29(12), 3241-3254. https://doi.org/10.1016/j.engstruct.2007.10.005

\section{Appendix 1}

Table 1. Calculation models provided in the analyzed design codes

\begin{tabular}{|c|c|}
\hline Design code & Key formulas of calculation model \\
\hline $\mathrm{EC} 2$ & $\begin{array}{c}V_{c 1}=\left[C_{c} \cdot k\left(100 \cdot \rho_{1} \cdot f_{c}\right)^{\frac{1}{3}}\right] b \cdot d \geq v_{c, \text { min }} \cdot b \cdot d \\
v_{c, \text { min }}=0.035 \cdot k^{3 / 2} \cdot f_{c}^{1 / 2} \\
k=1+\sqrt{\frac{200}{d}} \leq 2.0\end{array}$ \\
\hline EC2-SMM & $\begin{array}{c}V_{c}=\left(l_{b} \cdot \sin ^{2}\left(\theta_{s}\right)+c \cdot \sin \left(2 \cdot \theta_{s}\right)\right) \cdot f_{c s b} \cdot b \\
f_{c s b}=0.6 \cdot f_{c} \cdot v \\
\theta_{s}=\arctan \left(\theta_{s}\right)=\frac{h-c-c_{2}}{a} \\
v=0.6\left[1-\frac{f_{c}}{250}\right]\end{array}$ \\
\hline
\end{tabular}


End of Table 1

\begin{tabular}{|c|c|}
\hline Design code & Key formulas of calculation model \\
\hline STR2.05.05:2005 & $\begin{array}{c}V_{c}=\frac{\varphi_{c 4} \cdot\left(1+\varphi_{n}\right) \cdot f_{c t d} \cdot b \cdot d^{2}}{c} \\
V_{c, \min }=\varphi_{c 3} \cdot\left(1+\varphi_{n}\right) \cdot f_{c t d} \cdot b \cdot d \\
V_{c, \max }=2.5 \cdot f_{c t d} \cdot b \cdot d \\
c_{\max }=2.5 \cdot d\end{array}$ \\
\hline ACI-318 & $\begin{array}{c}V_{c}=\left(3.5-2.5 \frac{M_{u}}{V_{u}}\right)\left[0.156 \cdot \sqrt{f_{c}}+17.96 \cdot \rho_{1}\left(\frac{V_{u} \cdot d}{M_{u}}\right)\right] b \cdot d \\
1.0 \leq\left(3.5-2.5 \frac{M_{u}}{V_{u}}\right) \leq 2.5 \\
V_{c} \leq 0.5 \sqrt{f_{c}} \cdot b_{w} \cdot d\end{array}$ \\
\hline
\end{tabular}

$d$ is the effective beam height;

$a$ is the shear span;

$f_{c}$ is the compressive concrete strength;

$\rho_{l}$ is the amount of longitudinal reinforcement;

$b$ is the width of beam;

$l_{b}$ is the length of support plate;

$f_{y}$ is the yield strength of the longitudinal reinforcement.

Table 2. Experimental beams tested by various authors

\begin{tabular}{|c|c|c|c|c|c|}
\hline Author(s) & $b(\mathrm{~mm})$ & $a / d$ & $f_{c}(\mathrm{MPa})$ & $\rho_{l}$ & $\begin{array}{l}\text { Number of } \\
\text { specimens }\end{array}$ \\
\hline $\begin{array}{l}\text { Tan, Kong, Teng, and Guan (1995) } \\
\text { Tan, Cheng, and Cheong (2005) } \\
\text { Tan and Cheng (2006) }\end{array}$ & $110-140$ & $0.84-1.7$ & $32.7-77.6$ & 2.6 & 8 \\
\hline Zhang and Tan (2007) & $80-230$ & 1.1 & $28.3-32.4$ & $1.15-1.28$ & 8 \\
\hline Moody, Viest, Elstner, and Hognestad $(1954,1955)$ & 178 & $0.76-2$ & $17.8-41.5$ & $0.95-4.76$ & 51 \\
\hline Rogowsky, MacGregor, and Ong (1986) & $127-200$ & $1.05-2$ & $23.1-79.8$ & $1.12-3.34$ & 5 \\
\hline Ismail (2016) & $100-150$ & $0.91-1.67$ & $35.8-85.2$ & $1.38-3.83$ & 6 \\
\hline Morrow and Viest (1957) & 305 & $0.95-1.96$ & $12.7-46.8$ & $0.57-3.8$ & 22 \\
\hline Chang and Kesler (1958) & 137 & 1.85 & 14.9 & 2.37 & 1 \\
\hline Watstein and Mathey (1958) & 203 & 1.51 & $22.4-26.4$ & $0.75-3.05$ & 22 \\
\hline Rodriguez, Bianchini, Viest, and Kesler (1959) & $152-156$ & $1.36-1.38$ & $17.9-26.1$ & 1.59 & 6 \\
\hline de Cassio and Seiss (1960) & 152 & $1.52-2$ & $25.8-28.3$ & $1.35-3.33$ & 2 \\
\hline Leonhardt and Walther (1964) & 190 & $1-2$ & $22.3-38.1$ & $1.32-2.47$ & 10 \\
\hline de Pavia and Siess (1965) & $51-102$ & $0.67-1.34$ & $24.6-37$ & $0.83-1.67$ & 5 \\
\hline Kani (1967) & $149-157$ & $0.99-2$ & $17.4-35.2$ & $0.77-2.69$ & 20 \\
\hline Manuel (1974) & 102 & $0.9-1.06$ & $32.3-38.1$ & 1.88 & 2 \\
\hline Walraven and Lehwalter (1994) & 250 & $1-1.5$ & $15-26.4$ & $1.12-1.9$ & 19 \\
\hline Yang, Chung, Lee, and Eun (2003) & 160 & $1.06-1.13$ & $31.4-78.5$ & $0.97-1.05$ & 7 \\
\hline Smith and Vantsoitis (1982) & $100-102$ & $0.77-1.31$ & $13.1-21.7$ & $1.93-3$ & 5 \\
\hline Oh and Shin (2001) & 130 & $0.85-1.25$ & $23.7-49.1$ & 1.56 & 3 \\
\hline Adebar (2000) & 250 & $1.75-2$ & $19.5-20.3$ & $0.84-1.75$ & 3 \\
\hline Pendyala and Mendis (2000) & 80 & 2 & $63-87$ & 2.02 & 2 \\
\hline Shin, Lee, Moon, and Ghosh, (1999) & 110 & $1.13-1.69$ & 77.6 & 3.77 & 2 \\
\hline Xie, Ahmad, Yu, Hino, and Chung (1994) & 127 & $1-2$ & $41.4-47$ & 2.07 & 2 \\
\hline Niwa, Maekawa, and Okamura (1981) & 100 & 0.88 & 13.1 & 3 & 1 \\
\hline & & & & Total & 212 \\
\hline
\end{tabular}


Levon, B.; Šalna, R.; Juknevičius, L. 2019. Analysis of the different techniques for calculation of bearing capacity of flexural reinforced concrete deep beams

Table 3. The accuracy of calculation models

\begin{tabular}{|l|c|c|c|c|}
\hline Calculation model & EC2 & EC2 SSM & STR & ACI-318 \\
\hline Systematic error & 1.56 & 1.83 & 1.02 & 2.01 \\
\hline Random error & 0.46 & 0.62 & 0.26 & 0.7 \\
\hline
\end{tabular}

Table 4. Classification of models by DPC method

\begin{tabular}{|l|l|c|c|c|c|}
\hline \multirow{2}{*}{$V_{\text {test }} / V_{\text {calc }}$} & \multirow{2}{*}{ Classification } & \multicolumn{4}{|c|}{ Penalty points } \\
\cline { 3 - 6 } & & EC2 & EC2-SSM & STR2.05.05:2005 & ACI-318 \\
\hline$<0.5$ & Extremely dangerous & 0 & 0 & 0 & 0 \\
\hline $0.5-0.85$ & Dangerous & 14 & 16 & 68 & 1 \\
\hline $0.85-1.15$ & Appropriate safety & 34 & 27 & 78 & 18 \\
\hline $1.15-2$ & Conservative & 122 & 66 & 66 & 96 \\
\hline$\geq 2$ & Very conservative & 42 & 103 & 0 & 295 \\
\hline Sum & & 276 & 352 & 406 & $\mathbf{2}$ \\
\hline Range & & $\mathbf{1}$ & $\mathbf{3}$ & $\mathbf{4}$ & 97 \\
\hline
\end{tabular}

